II AY TRAYSFER FROA ELECTRICALLY HEATED :ODS

J!?! NG A SINULATED LOSS-OF-COOLANT ACCIJENT*

C. G. Lawson

Oak Ridge National Laboratory

Oak Ridge, Temncssee

To Be Presented at the American Institute of Chemical E'ngineers Annual Meeting,

San Francisco, California

November 29-December 2, 1971

This report was propared as an sccount of work sponsored by the United States Government. Nelther the United States nor the United States Atomic Energy Commiation, nor any of their employeas, nor any of thet contrectors, cubcontractors, or thet employees, makes any warranty, express or implied, or asumes any legal linbility or responsibility for the accuracy, completeness or usefulness of any information, spparatus, product or process disclosed, or represents that its we would not infringe privately owned rights.

\footnotetext{
$\star$
}

Research Sponsored by the U.S. Atomic Energy Commission Under Contract With Unian Carbide Corporation. 
Abstract

The loss of primary coolant from a pressurized water reactor as c. result of an instantaneous rupture of a main circulating line is called a LOCA and is perhaps the most serious accident in terms of radioactivity release from the fuel to the outer containment system that can be realistically postulated. Emergency Core Cooling Systems (ECCS) are provided to maintain continuity of energy removal from the reactor core following such an event. Paramount to the evaluation of the ECCS is knowledge of the fuel and fuel-clad temperatures at the end of the coolant loss period of 8 to 14 seconds. Heat-transfer data have not been available for the conditions of heater power (heat flux) and of trensient coolant pressure, velocity, and temperature comparable to the environment around a fuel-rod bundle during a loss-of-coolant transient. Appropriate transient heat-transfer data have now been obtained with single Zircaloy clad heaters (0.5-in. -OD $\times$ 2-ft-long) and a seven-rod cluster in a closed cycle, circulating, 1500 psi pressurized, water 100p at power levels of $17.5 \mathrm{kw} / \mathrm{ft}\left(450,000 \mathrm{Btu} / \mathrm{hr}\right.$ oft $\left.\mathrm{ft}^{2}\right)$ with cooling water near $500^{\circ} \mathrm{F}$ inlet and 1500 psi during a 12-second depressurization and coolant loss. Flow regimes associated with bulk-mucleate boiling and with thin film surface evaporation are clearly disceznible where the temperature difference and heat flux data are cousidered. The high heat-transfer coefficients were observed for times : greater than the heat-removal time constants of the heater rods and suggest that assumptions made in current calculations are conservative.

\section{Key Worâs}

Unsiteady Flow-Multi Phase, Heat Transmission-Unsteady Flow, Nuclear Fuel Assemblies, Nuclear Fuel Cladding-Zirconium, Nuslear Reactor Accidents, Nuclear Reactor Bngineering, Pressurized Water Reactore, - and Pressure Reduction 
HEAT TRANSFYR FROM ELECTRICALLY HEATED ROUS

DURING A SIHULATED LOSS-OF-COOLANT ACCIDENT* In a preveninfowath idearto

\section{G. Lawson}

Oak Ridge National Laboratory

\section{The Loss-of-Coolant Accident (LOCA) is a design basis} accident that is evaluated as part of the information presented to the Atomic Energy Conmission in support of an application for a nuclear power plant construc-

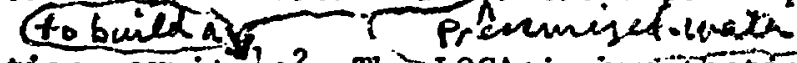

tion permit.',2 Thè a cimplete ard

presupposes the instantaneous rupture of one piimary coolant circulating pipe line, typically $\sim 2.5$ ft in dianeter, with the nuclear stean generator at full power. As consequence of the Instantaneous large pipe rupture, is the coolant and coolant pressure are releassd from the primary system in about ten seconds and the coolant is contained in the containment she11. Loss of the coolant, which moderates the neutrons, stops all energy production except the energy assoclated with the fission products contained in the fuel pins. This remalning energy release rate is

. about five percent of the operating power ten seconds

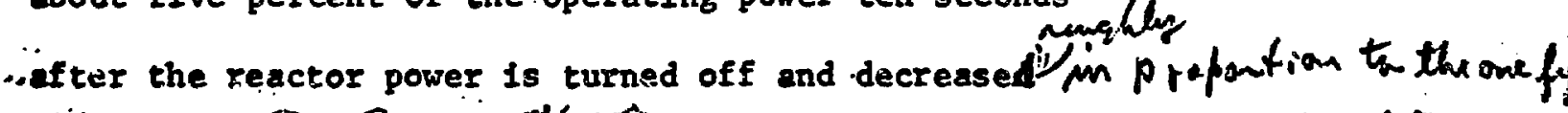
$\therefore$ Cropoteronaly to $\widehat{\alpha}$ time $\widehat{\theta 0,2}$. Emergency Core cooling rawer of taine

Systems (ECCS) are included in all waier reactor power plants to maintain the continuous cooling of : the coire by the rapid.addition to the reactor vessel 
of water poisoned against neutrons from pressurized storage tanks and pumped powis and by the contfinued circulation of this coolant through a special heat removal system. Successful operation of the ECCS is achieved within the context of the LOCA by assuring that the thermal energy released from the core during the accident does not damage the plant containment system. This assurance is achieved by maintaining the Integrity of the reactor core fuel pins. We now discuss briefly the core geometry, the core maturials and some thermal effects that may occur in order to demonstrate the need for rapid heat removal.

The fuel pins of pressurized water reactors are made of cylindrical uranium dioxide ceramic pellets housed in a Zircaloy tube. The pins have an active length of $12 \mathrm{ft}$ and Zircaloy tubes are rypically 0.420-in. OD by 0.026-in. wall. The surface heat flux has an average value of about 150,000 to a maximum of about $550,000 \mathrm{Btu} / \mathrm{hr}^{\mathrm{ft}} \mathrm{ft}^{2}$. The pins are ar-

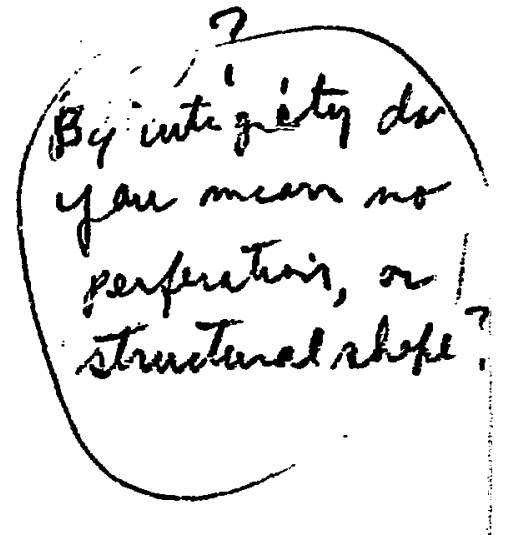
ranged Into a fuel assemb ly as a $15 \times 15$ square array. Assemblies are folned together to form a reactor core approximately $12 \mathrm{ft}$ diameter. There is a coolant gap of about $0.125-i n$. between pins resulting in a matrix that is slightly more than $50 \%$ coolant by volume. The copiant flow through the core is bottom to top.. and paralle l to the fuel pin axis. The fuel pins contain pressurized inert gas, heifum or argon, sded 
during fabrication as a purge for oxygen, nitrogen and molsture.

The fission process also generates gaseous fission products xenon and krypton which are released to the fuel pin cavity such that the internal pressure of the fucl pins nay vary during reactor operation up to the reactor coolant pressure of 2200 psig. During normal operating conditions this would result in a tangential stress that is compressive. During a LOCA, the tangential stress becones tensile. The tangential tensile stress is typically one-seventh of the outward directed pressure difference due to geometry.

In Table 1 is a listing of temperatures, In ascending order, that rejate the thermail conditions that exist in the reactor fivel with the significant temperature boundaries describing the physical accurrences In the cladding and fuel.

There are two potential siltuations for retrograde type cladding fallure that are of concern even though they bath requfre muitiple and coinclidental malfunctions thetr occurrence unlikely, ince

$\because$ The first of these accurs diring or shortly after the coolant depressurization caused by the fallure of a large circulating line; a time period from 10 to 30 seconds. Should a pịpeline break and the emergency coolant injection not function, or should the core remain gteam birmkéted and uncooled for several seconds 
Table I. Critical Temperature Limits of Fuel Rods

Temperature ( $\left.{ }^{\circ} \mathrm{F}\right)$

Related Conditions

6.50

Pressurizer Saturation Pressure; approximate temperature of cladding surface.

1300

Approximate average fuel temperature in core at normal operating condition

$1500 \pm \frac{300}{200}$

$21600 \pm 100$

Cladjing swells and ruptures due to excessive tangential stress. Abcut 45\% tangential stress blocks flow channel.

$\sim 1900$

Zirconium a to $B$ phase transportation, anneal is rapid.

Eutectic formation between Zircalloy and Ferrous alloys. (Normal oxide coatings act as barrier to interaction.)

$\checkmark 2100$

Exothert 'c Zirconium-steam reaction becomes significant, heat generated $\simeq$ decay heat rates.

थ2500

Zirconium Oxide diffuses into Zircaloy and erabrittles base metal at rapld rate.

22600

Average fuel temperature at high flux locations.

$\checkmark 2800$

cooling posstble by water quench only.

3300

Zircontum melts. Fission product re-

- . . lease from $\mathrm{UO}_{2}$.

25000

Matrix Increases as temperature increases. Uranium Oxide and Zirconium Oxide melt. 
lumel af.

before the thermal energy storcd in the fuel is removed, then many of the rods could reach surface temperature in the range of 1200 to $2200^{\circ} \mathrm{F}$ in several seconds.1,2 In this temperature rarige the ultinate stress of Zircaloy drops from about 11,500 to about 300 psig $^{4}$ which corresponds to rod internai pressures of 1600 and 43 psig. Above about $1700^{\circ} \mathrm{F}$, and with Internal pressures below 150 psi, the cladding is ductile and expands rapidly and extensively before rupturing when heated at rates between 10 and $200^{\circ} \mathrm{F} / \mathrm{sec}-$ ond. 5 For fuel rods with an internal gas pressure below about 200 psi that are subjected to this temperature range, there is a distinct pcssibility of block$260 \mathrm{~s}$ :5 in Take
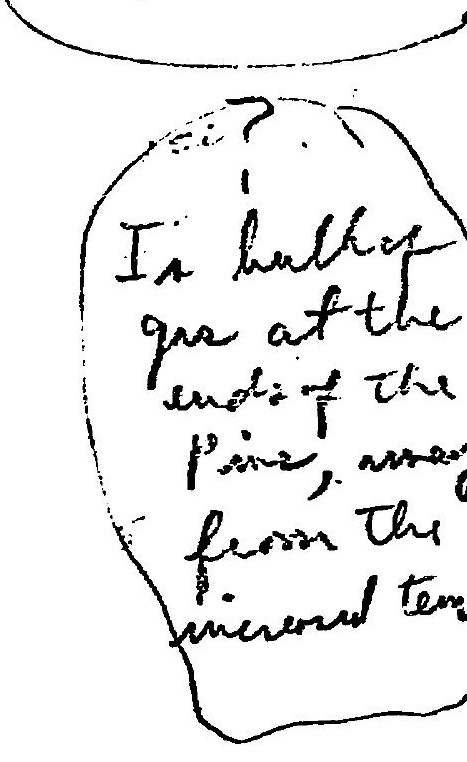

sive clad swelling. 12 Relatively small blisters are Iormed with longitudinal cracks at $1500^{\circ} \mathrm{F}$ and $600 \mathrm{psi}$ Internal pressures. Above 600 psi the Zircaloy expands at temperatures below $1500^{\circ} \mathrm{F}$ in a ductile manner.

The second mode of fuel failure might exist if the cooling is marginal and the zircaloy cladding is maintained for several minutes above about $2400^{\circ} \mathrm{F}$ in $\because$ contact with stean. Under these conditions, the Zircaloy is oxidized. The presence of zirconium oxide embrittles the metal which may be easily shattered, craciced, or broken when the temperature of the fuel 
rods is finally lowered. There is some concern that the rubbje produced could block fion channels and be difficul.t to cool.

The experimental work currently being performed in the PUk Ful1 Length Energency Cooling Heat Transfer Program (FLECHI) is being performed mostly with stainless steel clad heater rods that are not internally pressurized. 7,8 These tests are designed as "proof tests" to demonstrate the cooling capability of the emergency systems. Tests are conducted at a constant pressure near one atmosphere, with the cladding heated to an initial temperature from 1300 to $2100^{\circ} \mathrm{F}$ and decay heat power levels. The tests conducted at high initial tempsrature conditions resulted in cladding temperatures above $2400^{\circ} \mathrm{F}$ and heater failure. Since the tests were performed with non-pressurized heater rods, the effects of swollen or blistered rods $\therefore$ was not determined.

The FLECHT tests have shown, however, that more Information is required on thermal energy removal durIng the coolant loss period of a loss-of-coolant acci“dent. This information will hel establish more realistic bounds on the temperature of the fuel cladding -when the emergency coolant is injected. In addition, it is apparent now that the temperature range of interest to the Emergency Cooling System perionmance requires the use of zircaloy cladaing in experimental 
programs becausc: (1) it is the naterial of interest, and (2) it has a high ductility and relatively low (funt)pressurz compared to the stainless steel used in the past, and (3) the chemical-metallurgical-mechanica1 properties interaction is unique above about $1500^{\circ} \mathrm{F}$.

The experimental and analytical effort required to define the failure mode for Zircaloy cladding subjected to the above sets of conditions is different for the first and second mode. The first failure mode requires a study of: the transient thermal and mechanical stresses on the clad associated. with the blowdown and with the heatup following the blowdown. The second failure mode requires information of stress-strain fracture in Zircaloy clad enbrittled by hydrogen, oxygen, and possibly other gases.

This paper is a report of some work currently in progress at the Oak Ridge National Laboratory to obtain data on simulated fuel rods in a typical depressurization accident. . The data of particular interest are the thermal responses of the rods, since if the

cladaling is kept cool the rods will undergo only small dimensional changes.

Previous experimental work on transient blowdown that

heat transfer concluded ${ }_{\Lambda}$ steady state correlation could be utilized, The tests were performed with pressure 
Table II. Comparison of Test Variable to Reactor Condition

\begin{tabular}{|c|c|c|}
\hline Varlable & Test Condition & $\begin{array}{l}\text { Reactor Condition } \\
\text { (PWR) }\end{array}$ \\
\hline Inlet water pressure, psia, $p$ & 1515 & 2250 \\
\hline Inlet water temperature, ${ }^{\circ} \mathrm{F}$ & 500 & 545 \\
\hline Inlet water velocity, ft/sec & 2 and $5 *$ & $\sim 15$ \\
\hline $\begin{array}{l}\text { Inlet water saturation pressure, } \\
\text { psla, } p_{1} \text {, sat }\end{array}$ & 680 & 1000 \\
\hline Inlet $\left(p=p_{i, s a t}\right)$ & 835 & 1250 \\
\hline Outlet water temperature, ${ }^{\circ} \mathrm{F}$ & 515 and 570 & 600 \\
\hline $\begin{array}{l}\text { Outlet water saturation pressure, } \\
\text { psi, } P_{0}\end{array}$ & 780 and 1226 & 1543 \\
\hline Outilet $\left(p-p_{0, s i t}\right) p s i$ & 735 and 250 & 707 \\
\hline Rod internal pressure, psi (max) & Not done & 2400 \\
\hline Rod length, in. heated & 24 & 144 \\
\hline Rod diameter, In. & 0.5 & 0.422 \\
\hline Gas plenum & $10 \%$ of rod volume & 210\% of rod yolume \\
\hline Type of tubing & Zircaloy IV & Zircaloy IV \\
\hline Wall thickness, in. & 0.035 & 0.026 \\
\hline Linear heat rating, $\mathrm{kW} / \mathrm{ft}$, $\max$. & $\begin{array}{l}\text { w8 uniform } \\
\text { distribution }\end{array}$ & $\begin{array}{l}\text { } 18 \text { maximum } \\
\text { cosine dist. }\end{array}$ \\
\hline $\begin{array}{l}\text { Temperature rise rate at } 18 \mathrm{~kW} / \mathrm{Ft} \text {, } \\
\text { (Adiabatic, }{ }^{\circ} \mathrm{F} / \mathrm{sec} \text { ) }\end{array}$ & $\sim 300$ & 400 \\
\hline $\begin{array}{l}\text { Average rod temperature at } \\
18 \mathrm{~kW} / \mathrm{ft}, 0 \mathrm{~F}\end{array}$ & 1900 & $\sim 2500$ \\
\hline Geometries & $\begin{array}{l}\text { Both single rod and } \\
\text { 7-rod clusters in a } \\
\text { triangular array }\end{array}$ & Square array \\
\hline $\begin{array}{l}\text { Coeficicient of linear exp } \\
1 /^{\circ} \mathrm{C} \text { of filler. }\end{array}$ & $211 \times 10^{-6}(80 \% \mathrm{MgO})$ & $\sim 10 \times 10^{-6}\left(\mathrm{UO}_{2}\right)$ \\
\hline Fuel time constant & $\begin{array}{l}7 \text { seconds (no gas } \\
\text { gap.) }\end{array}$ & $\begin{array}{l}4.5 \text { to } 5.5 \text { seconds } \\
\text { (no gap) }\end{array}$ \\
\hline · & $\begin{array}{l}\text { Up to } 15 \text { seconds } \\
\text { (with gas gap) }\end{array}$ & Unknown (with gap) \\
\hline $\begin{array}{l}\text { Effective heat conductance; } \\
\text { Btu/hr:ft }{ }^{2} \cdot{ }^{\circ} \mathrm{F}\end{array}$ & थ285 & ح330 \\
\hline
\end{tabular}


transients thal are slow relative to a postulated reactor depressurizaljon. ${ }^{1.1}$

Heater rods clad with zircaloy and operable at a heat flux and a stored thermal energy comparable to fuel rods were developed as was a closed cycle loop in which the depressurization tests were performed. These two itens are discussed below.

\section{The Depressurization Loop}

The depressurization loop is shorn schematically In Fig. 1. The operating conditions are listed in

Table II, and compared with a PWR plant. The loop consjists of a high-pressure closed loop and a lowpressure or energy absorption tank. The high-pressure and low-pressure systems are isolated from each other through a pair of rupture discs confining a buffer pressure zone.

The high-pressure (i500 psia) systems contain a 100-gpm canned rotor pump, a pressurizer, a heat exchanger, and a bypass line as well as a location for flanging in a test section. The test section utilizes

- a. power supply of seven separately controllable varilacs of 1800 amps, 230 volts each. Flow, pressure, temperature, and other normal operating instrumentation were included. - Steady -state flow data are determined in the test section and the bypass line. Transient data are obtained from pressure transducers and 


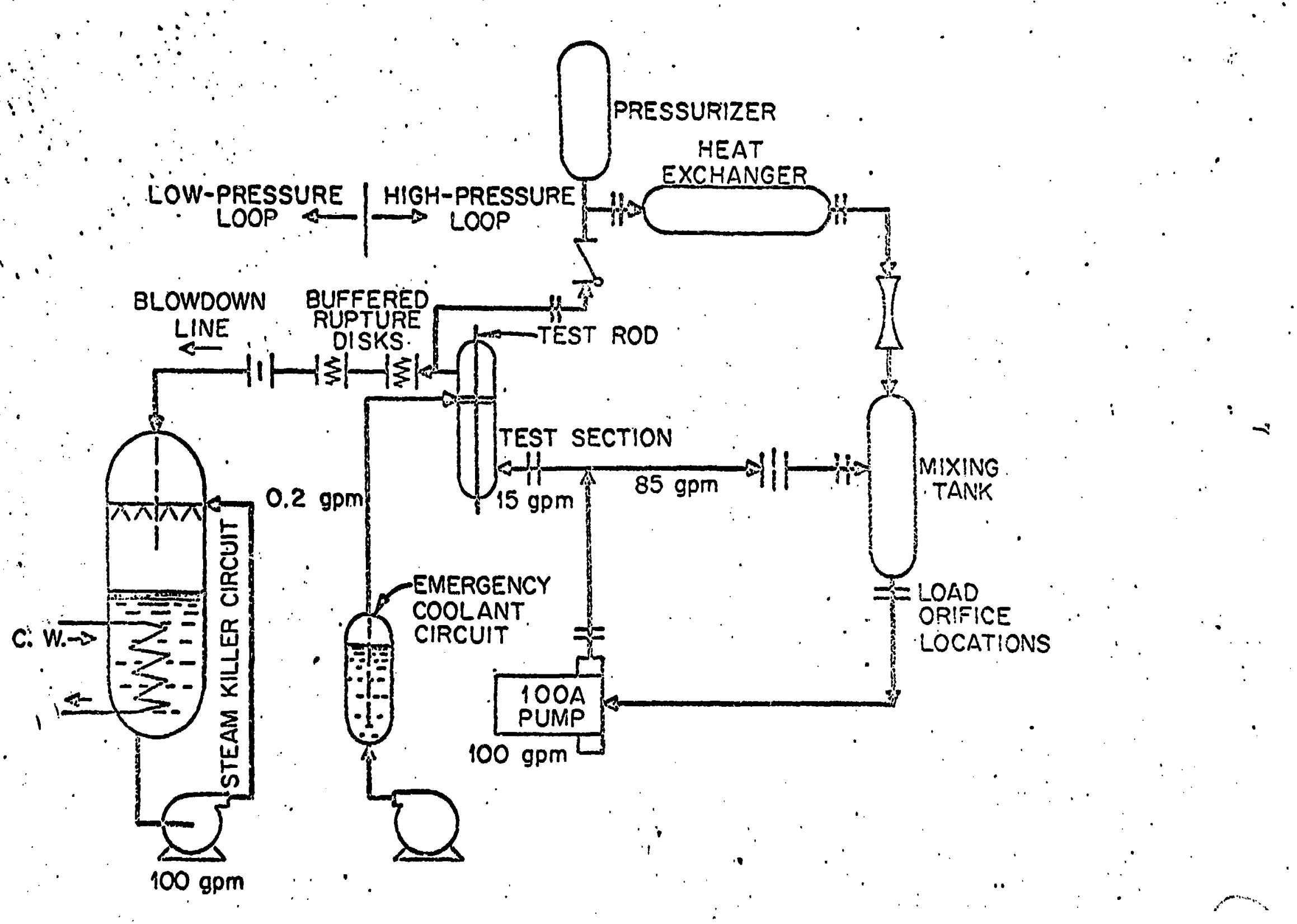


thermocouples located throughout the loop and on the test rods. The depressurization time to $100 \mathrm{psia}$ is controlled from about 7 to 60 seconds by varying the diameter of a critical flow orifice located near the rupture disks. The pressure transducer output is recorded on an FM recorder, and the thermocouple data are converted from an analosue to a digital signal and recorded in turn on a magnetic tape at a combined speed of 600 data points per second. The low-pressure system is essentially a large tank with cold water to absorb the blowdown energy; a 100 gpm pump circulated cold water to condense the steam. In addition, a water injection pump supplies water for cooling the Zircaloy rod after the blowdown by means of a spray and a flaod Iine from the water supply at $100 \mathrm{psi}$.

A typical test included the following steps:

I. Installation of test section with zircaloy rod.

2. Heatup of loop and establishment of steady-state, fncluding

a. test rod operating at $\sim 19 \mathrm{~kW} / \mathrm{ft}$ of rods,

b. temperature across test section, inlet at

$\therefore \quad \therefore 500^{\circ} \mathrm{F}$, outlet at $515^{\circ} \mathrm{F}$,

c. Locp pressure at 1500 psia.

3. Blowdown initiation by increasing the gas buffer pressure between rupture disks and pump power cut out.

4. High-speed recording of pressure and temperature 
5. Power level reduced to simulate decay heat.

6. Water injection initiated by "sigual of Zircaloyclaclding tenperature or at a preset time.

7. Continued recording on moderate speed recorders until rod is quenched.

8. Loop cooldown and removal of test section.

9. Photographic examination of rods; measurement of rods.

10. Analysis of data.

The Heater Rods

The 1/2-in.-diam Zircaloy-clad. rods had a heated length of 2 feet; the internal heaters were made from Kanthal A-1 wire and were contained with magnesium oxide insulation. A heater sketch is shown in Fig. 2. A Pt to Pt-10\% Ph thermocouple measured the centerline temperature. The magnessium oxide of the heater rod has a thermal diffusivity and a product of specific heat $X$ density which are .038 and 52 as compared with $.053 \mathrm{ft}^{2} / \mathrm{hr}$ and $45.7 \mathrm{Btu} / \mathrm{ft}^{3}$ for $\mathrm{UO}_{2}$. Thus the transient thermal behavior of the heater is comparable to 'the fuel rod. This stored thermal energy in the heated rods is comparable to that in the fuel rods, since the weighted mean temperature for the heater rod in above the sempere tandenatine by

to about $3 / 4$ of the maximuni radial temperature difference rather than $1 / 2$ as in the case for a fuel rod which hạs a distribuced heat source.

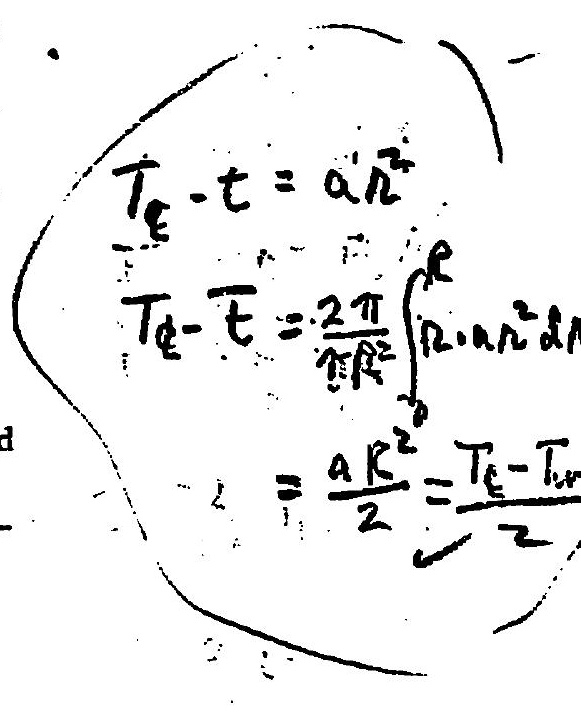




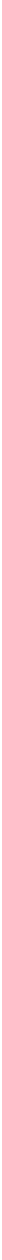


These henters have been operated for short times with centerline tenperatures up to $2300^{\circ} \mathrm{F}$. The rods were operatcd at heat fluxes to $5 \times 10^{5} \mathrm{Btu} / \mathrm{hr} \cdot \mathrm{ft}^{2}$. (19 $\mathrm{kW} / \mathrm{ft}$ ) in subcooled boiling water at atmospheric pressure and to $4.75 \times 10^{5} \mathrm{Btu} / \mathrm{hr} \cdot \mathrm{ft}^{2}(18.5 \mathrm{~kW} / \mathrm{ft})$ in

$500^{\circ} \mathrm{F}$ water at $1500 \mathrm{psi}$. These heat flux and temperature levels are higher than the values for the hot rod average in a water reactor, but slightly lower than the hot spot values. We believe, therefore, that these heated rods may be used to simulate the thermal behavior of fuel rods during a LOCA. (The radiation embrittlement effects appear to be annealed out as the nietal approaches the phase transformation of about $1500^{\circ} \mathrm{F}$

Tests wherein the rod-1nternals were repeatedly heated, while the cladding surface was kept cool, indicate that the clad expanded plastically as a result of either long-term operation or operation at increasIng power levels. 6 This was determined by measuring the clad diameter before and after operation and comparing these measurements with the calculated rod ex-pansion. This gap increases the resistance to heat flow. The temperature of the rod Internals' Increased during prolonged steady-power operation with a new rod as the gap developed. The temperature also showed an Increase when the rod.was returned to the intial power

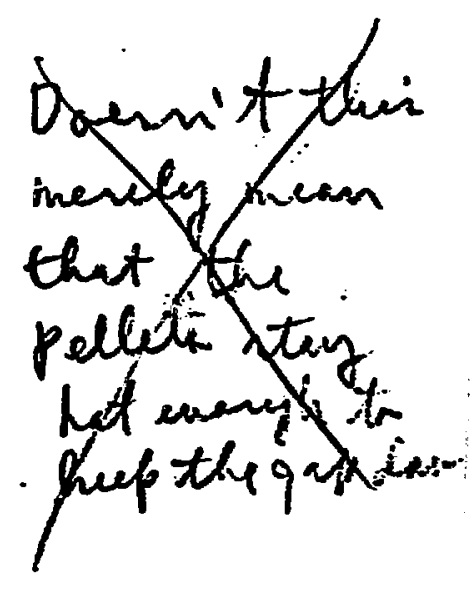


level following a power increase and decrease; this is shown in rig. 3.

During a decrease-jin-power transient, the heat retioval rate decreased as a result of the associated lower heat-transfer coefficient in the rod. This lattox: cffect is shown in Fig. 4, where the reduced temperature is plotted versus time for different rods at the begiuning and end of use. The thermal decay times of the rods was about 7 seconds for a new and $\sim 15$ seconds for an old rod. Fuel rods in PWRs have a smaller diameter and a time constant with no gas gap present of 4 to 5 seconds.

A sample heater rod (see Fig. 2) designed for internal pressurization has been tested in atmospheric pressure steam with an internal argon gas pressure of 400 ps 1 to determine whether the gas could diffuse through the heater and impose its stress on the Zircaloy cladding. The rod ruptured at $2450^{\circ} \mathrm{F}$ and a stress of about 3000 psi. This result is in agreement with previously published data. 4 Diametral expansion measured after the rupture varied from 0.01 in. to 0.113 in. (Fig. 5) along the heated length (from 2 to 22\%) with the maximum at the break; the diametral expansion was greater than $6 \%$ in $60 \%$ of the heated zone. This cest denonstrated the ability of the gas to spread rapidly through the ceramic filler of the heater rod. Thus, we belleve we can use this rod to simulate the 


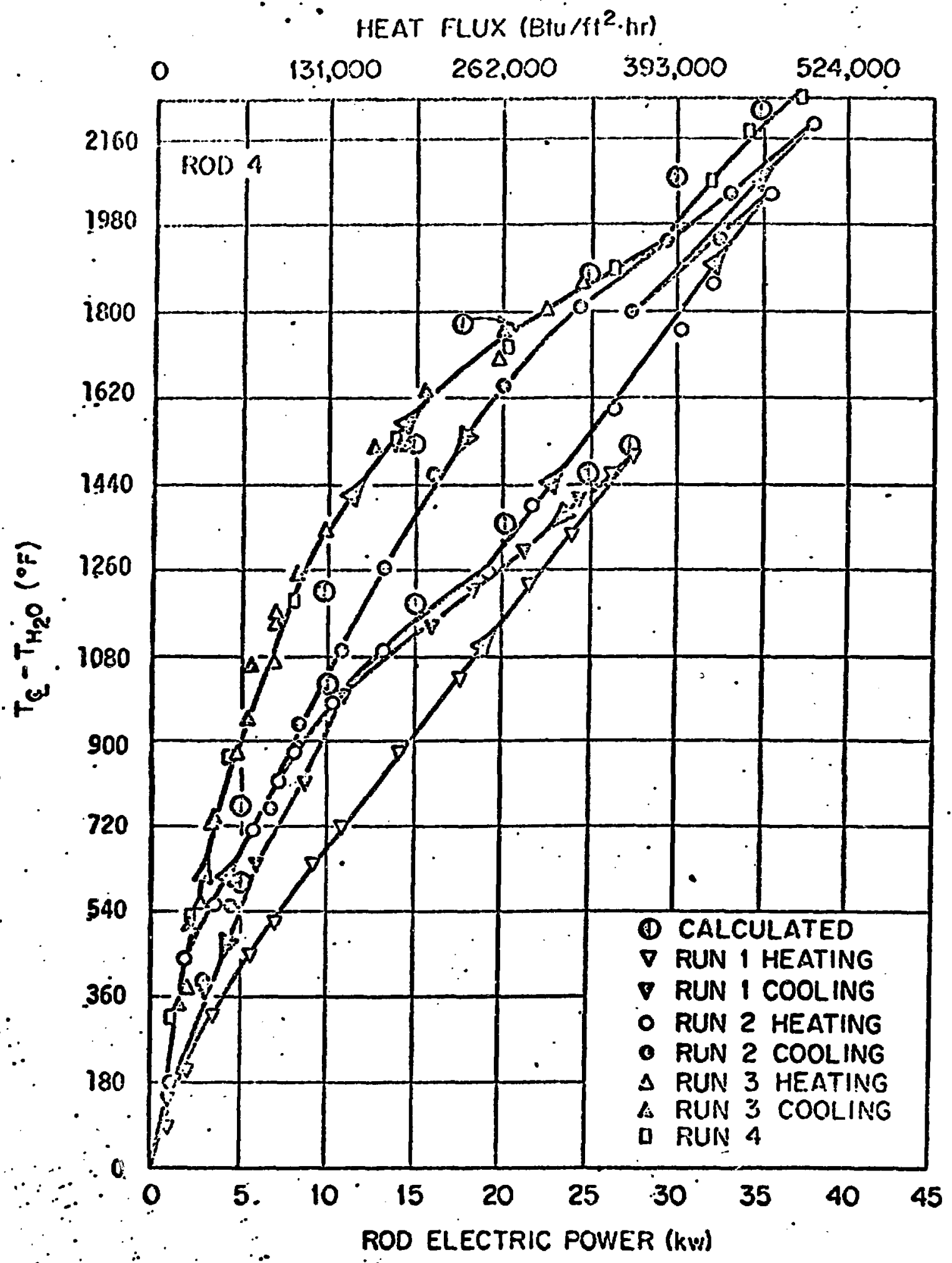


ORRLL- D\$G 70-234

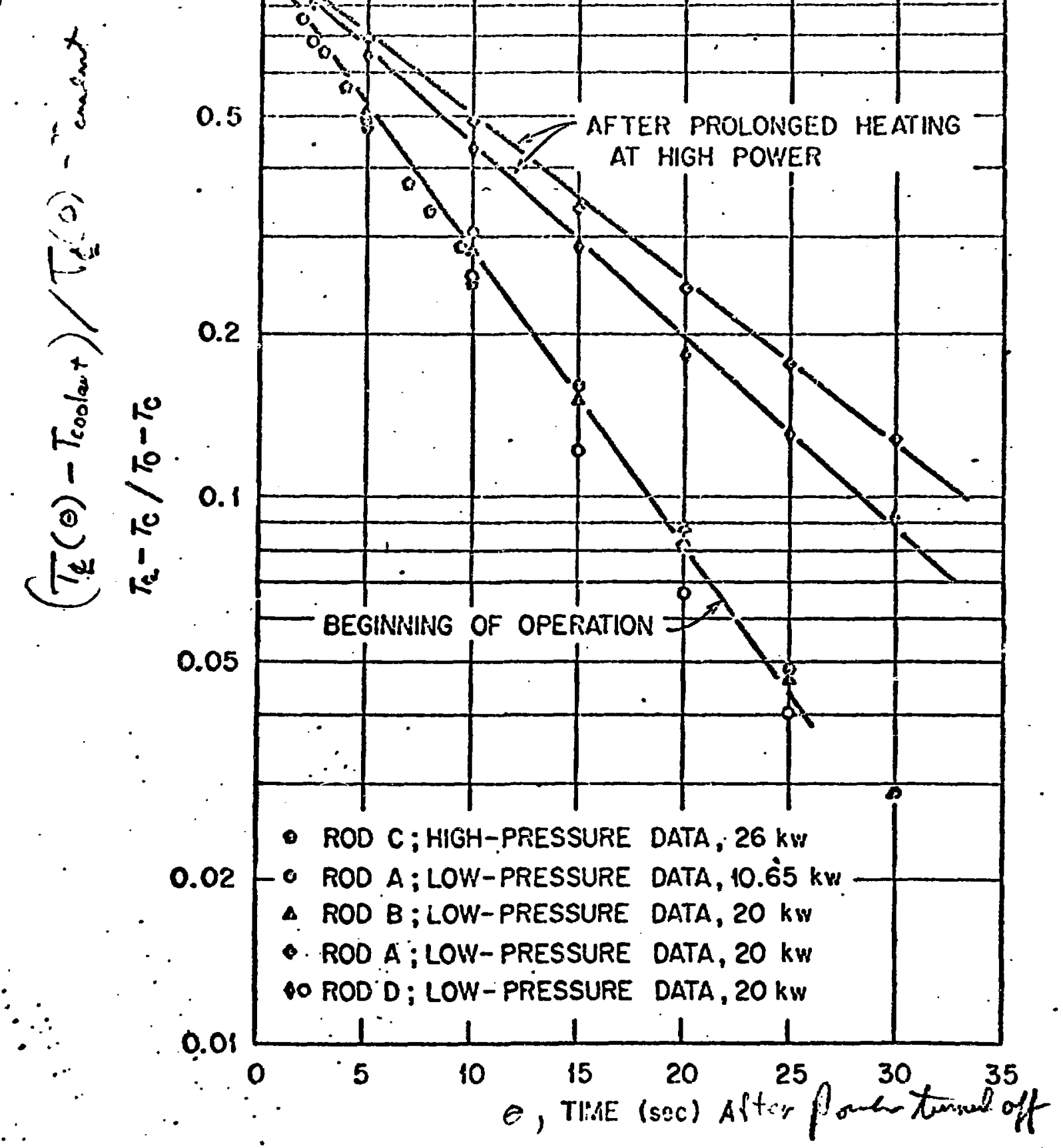

FIG. 4. COAPARISON OF TIME CONSTANT DATA OBTAIMED DURING DEPRESSURIZATION TESTS WITH LOH PRESSUURE DATA. 
EXPANSION OF OOOH:DIAMETER

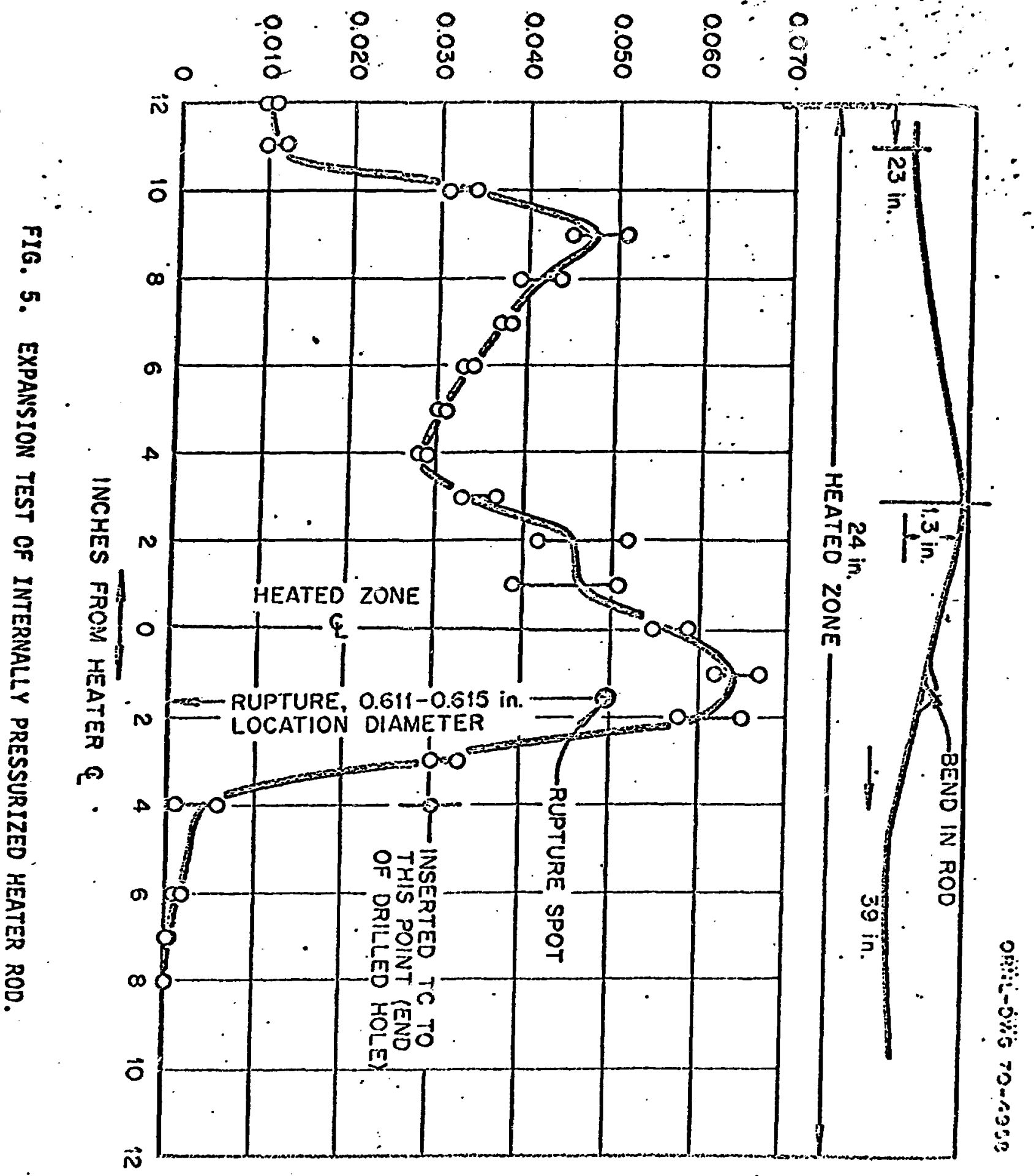


swelling and rupture characteristics of Zircaloy cladding by pressurizing the heater rods internally to simulace the fission gas internal pressure. (The radiation embrittlenent is annealed out if rupture occurs ri

above about $1500^{\circ} \mathrm{F} \cdot{ }^{i}$ )

\section{Depressurization Tests and Results}

Seven single-rod tests and one test with a seven rod cluster have been completed wherein time traces were measured on the coolant pressure, the heater centerline temperatures and the heater cladding temperatures.

The coolant discharge time was 12 seconds in four of these tests, including the seven rod cluster, and about 60 seconds in the renainder.

In the 60 second tests the rod power, initially set at steady levels that varied from 13 to 17.5 $\mathrm{kW} / \mathrm{ft}\left(342,000\right.$ to $\left.450,000 \mathrm{Btu} / \mathrm{hr} \cdot \mathrm{ft}^{2} \cdot{ }^{\circ} \mathrm{F}\right)$, was maintained when the loop rupture was initiated. About 4 to 8 seconds after rupture, the power was reduced to about $10 \%$ of the original level. All of these tests - showed that the cladding temperature and the measured water temperature in the rod flow channels followed each other closely until the loop pressure was near atwospheric pressure; these two temperatures then diverged rapidly. We interpreted this to mean that 
heat-transfer coefficients greater than $\sim 10000$

Btu/hr $\cdot \mathrm{ft}^{2} \cdot{ }^{\circ} \mathrm{F}$ existed until the flow section was out of water at which time the surface temperature increased rapidly while the remaining stored energy in the rod was being redistributed. 6 Typical data are shown in Fig. 6, wherein the thernal response of the F6 clad-surface and the rod-centerline temperatures and of the lcop pressure are depicted as a function of time after rupture. Saturation temperatures of the coolant are also plotted. We observe that the coolant and clad temperatures are close together until the loop is near atmospheric pressure at which time the two temperatures diverge. The effect of the gap between the clad and filler is clearly seen as follows: The temperature difference between the cladding and the centerline at 25 to 50 seconds corresponds closely to the temperatue différence which would be estimated from Fig. 3 for a rod operating at $3 \mathrm{~kW}(1.5 \mathrm{~kW} / \mathrm{ft})$. after operation at $28 \mathrm{~kW}$. These data had been recorded on a strip chart and the resolution was limited to $\pm 25^{\circ} \mathrm{F}$.

$\therefore$ The data recording system was improved to obtain .$\cdot$

the temperature difference between the cladding and the coolant. The results recorded with this system for a 12 second depressurization test are shown in F1g. 7." The test section coolant pressure and the 


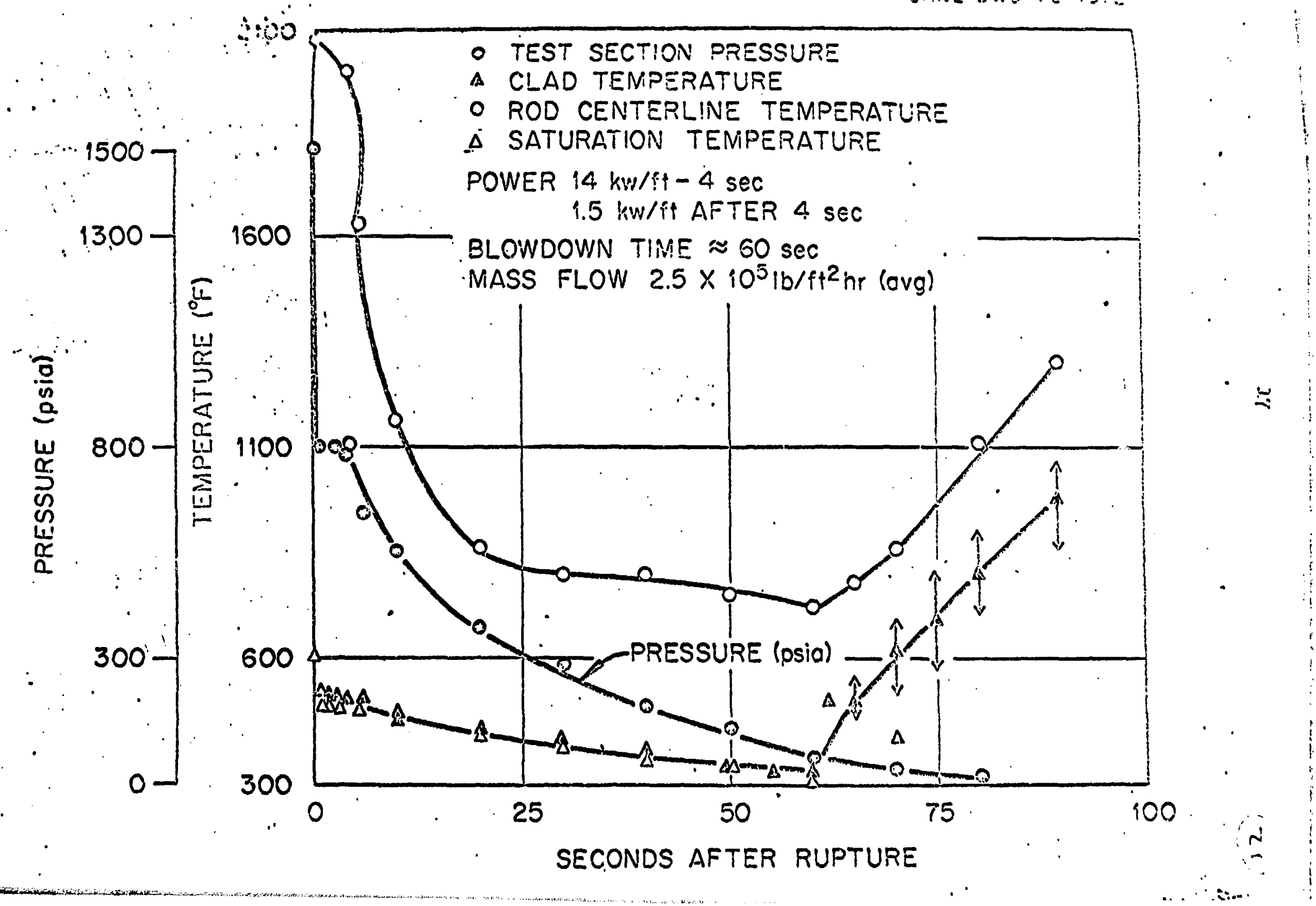


ORNL-OWE 70-4957

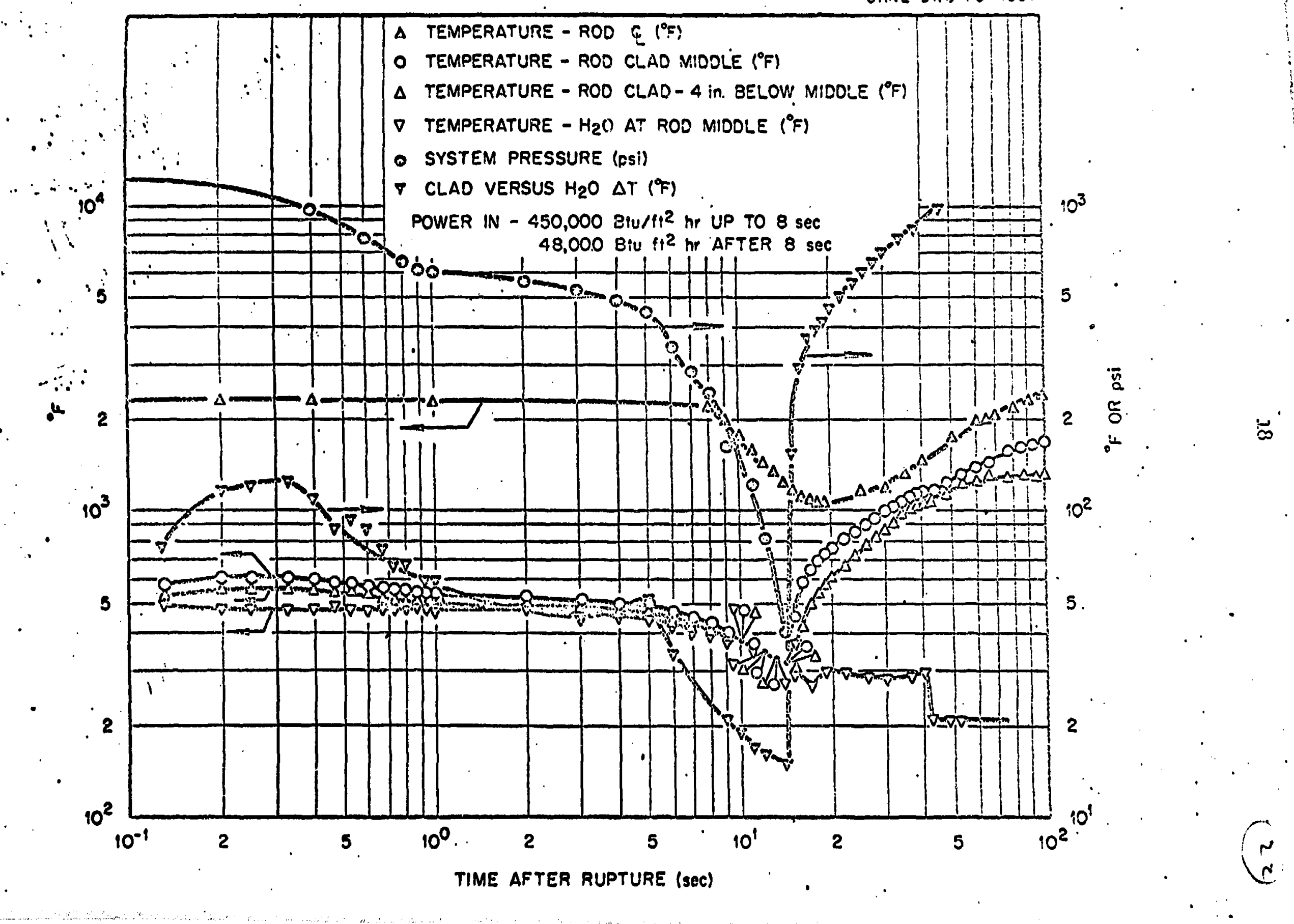


temperature difference between the clad and the coolant at the heater midplane are plotted on the right hand scale. In this test trie power input was held at $17.5 \mathrm{~kW} / \mathrm{ft}$ during the first 8 seconds after pipe rupture and the poiver was then lowered to $1.87 \mathrm{~kW} / \mathrm{ft}$ $\left(450,000\right.$ and $48,000 \mathrm{Btu} / \mathrm{hr} \cdot \mathrm{ft}^{2}$, respectively). Both the cladding tenperature and the heater central tenperature underwent only slight changes in the first 8 seconds. The plot of $\Delta T$ versus time suggests at about 0.8 seconds the development of bulk boiling front subcooled boiling concurrent with the loop pressure reaching saturation pressure. In addition, the relatively rapid decrease in clad-to-coolant $\Delta T$ starting at 5 seconds and continuing through about 14 seconds - is associated in time with the rapid decrease in system pressure starting. at about 450 psi some 5 seconds af ter rupture initiation. This sudden decrease in $\Delta T$ may be assoclated with the development of a thin liqufd film and annular two-phase flow around the rod due to the large steam volume and high ratio of steam-toIiquid volume associated with the rapid depressurization regime. The rapid rise in $\Delta T$ from about $15^{\circ} \mathrm{F}$ at 12 seconds to about $300^{\circ} \mathrm{F}$ two seconds later occurs when the loop coolant pressure is close to atmospheric pressure and the water has been discharged. The drop 


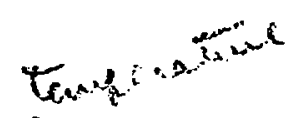

in coolant $\mathrm{T}^{\mathrm{T}}$ at 42 seconds is associated with the spray addilion of emergency coolant.

Heat-transier coefficients of 26000 to 3500

$\mathrm{Btu} / \mathrm{hr} \cdot \mathrm{ft}^{2} \cdot{ }^{\mathrm{C}} \mathrm{F}$ have been inferred for the pressurized portion, about $10,000 \mathrm{Btu} / \mathrm{hr} \cdot \mathrm{ft} \mathrm{t}^{2} \cdot{ }^{\circ} \mathrm{F}$ for the saturation bulk boiling portion, and about $15,000 \mathrm{Btu} / \mathrm{hr} \cdot \mathrm{ft}^{2} \cdot{ }^{\circ} \mathrm{F}$ in the annular flow or preburnout region of the depressurization curves. The heat-transfer coefficient at about 35 seconds is estimated at $10 \mathrm{Btu} / \mathrm{hr} \cdot \mathrm{ft}^{2} \cdot{ }^{\circ} \mathrm{F}$ and is about 20 to $25 \mathrm{Btu} / \mathrm{hr} \cdot \mathrm{ft}^{2} \cdot{ }^{\circ} \mathrm{F}$ after the water spray was turned on. These estimates were made from a two-region transient analysês assuming a radial temperature distribution in the ceramic element the same as in the steady state. These results are typical of this particular system only and are not typical of any particular reactor. The results of this and other experiments are to be examined by and compared with the calculated results of computer programs such as RELAP $3^{9}$ and THETA-1B 10 used in computing reactor tran-

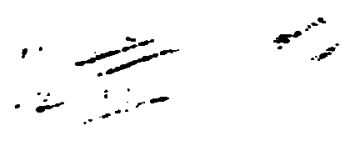
sients and thexmal results. These tests were per-

formed to assure the adequate development of both the heater rods and the experimental facility.

Data have been obtained on one cluster of 7 rods thlat show the thermal response and the pressure history during a depressurization. The heaters were identical to the single rod test heaters. The 7 rod array is shown in cross section in Fig. 8. 
21

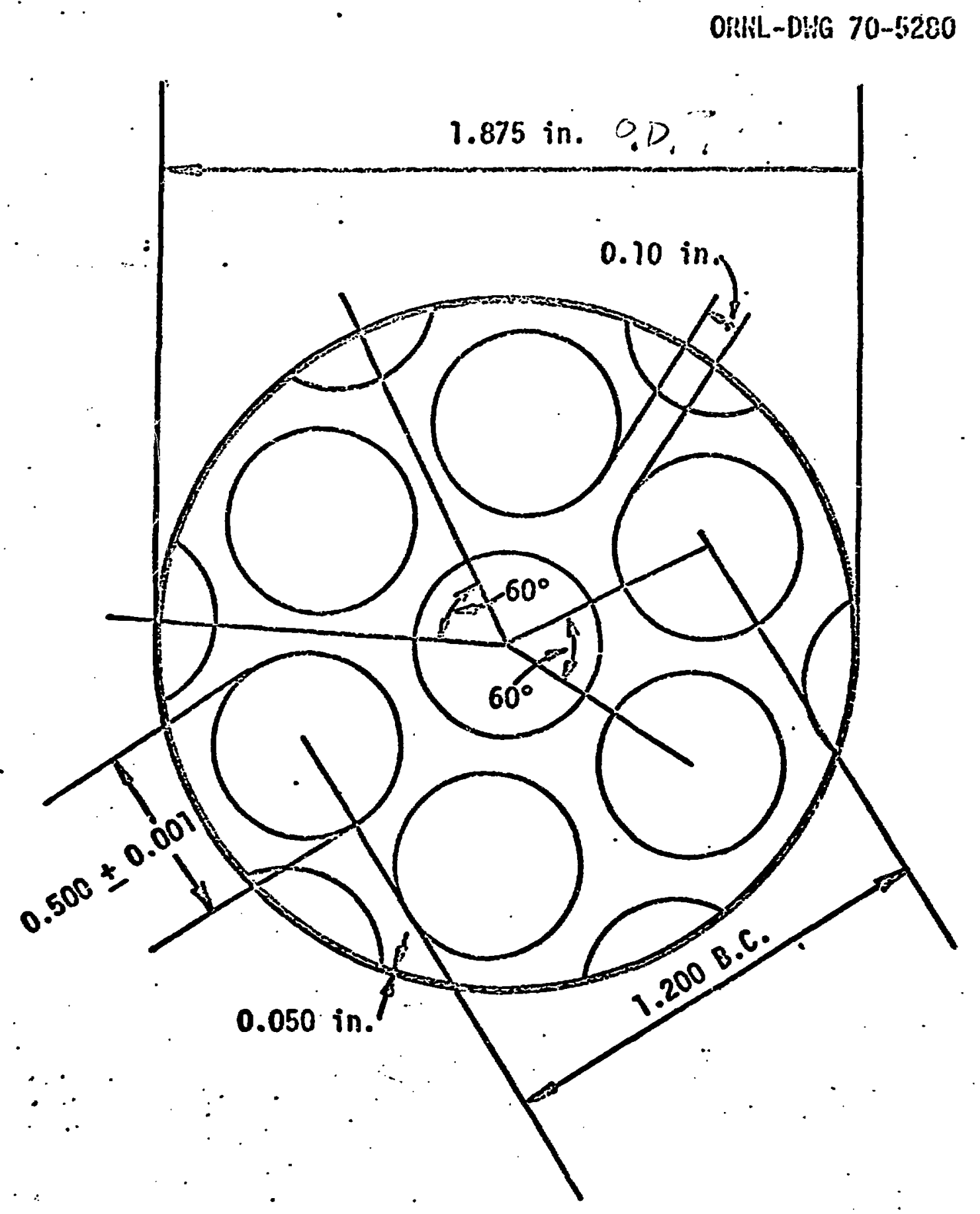

$\because$ FIG. 8. PLAN VIEH OF TEST SEVEN-ROD CLUSTER. 
The systen was operated vith a power input to the test rods of $166.2 \mathrm{~kW}$. The power distribution to the rods was as given in lable III. The average linear power rating for all rods was $11.9 \mathrm{~kW} / \mathrm{ft}$, which is comparable to the rating of the nominal high-power rods in a PWR. During the depressurization of the loop there was full power to the rods until interrupted by the loop safety circuits ( 15 sec of full power after start of depressurization). Since the power was not reduced to simulate shutdown, the experiment was conservative in terms of heat flux from the rods during the simulated LOCA.

Flow-resistance orffices were positioned in the 10op circulating system (see Fig. 1) to minimize coolant flow through the test section during the depressurization. The check valve and all flow resistances In the Iine between the mixing tank, heat exchanger, preseurizer, and blowdown line were removed, and all load orifices were placed in the line between the mixIng tank, pump, test section bypass, and the test section. Power to the pump was turned off when the depressurization was inftlated to further minimize flow through the test section.

The temperature on the center heater rod, rod 7 , and coolant temperature and pressure are shown on Fig: 9. Curves are shown for the temperature of the center 


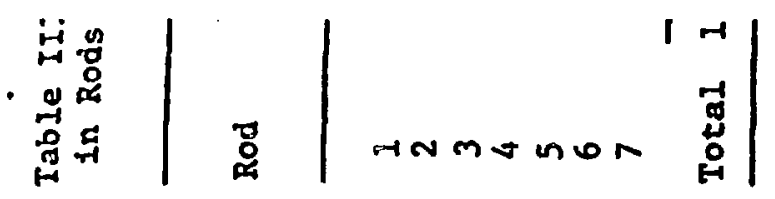

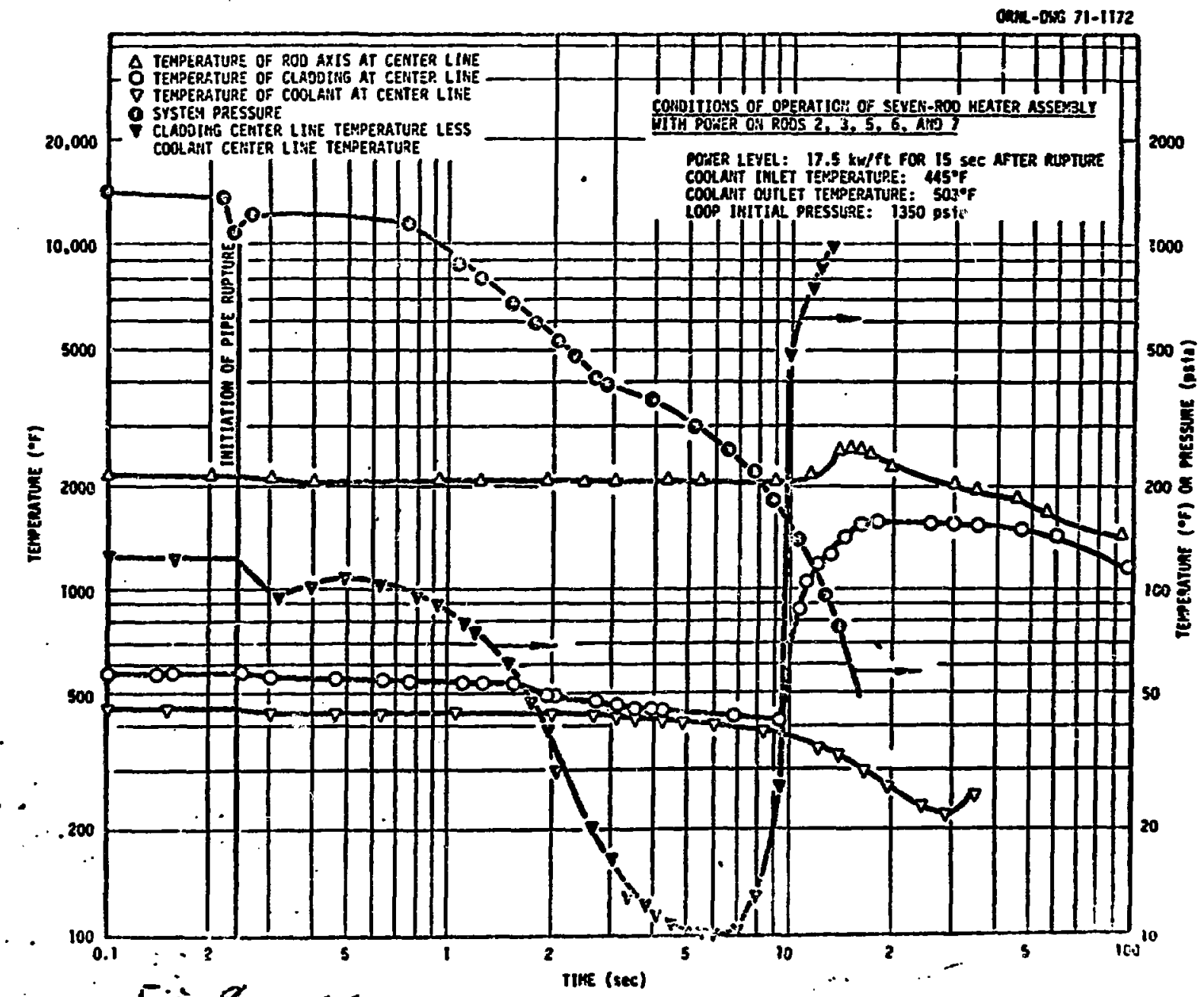

.$\cdots$
Fign 8 THE (sec) 
of the rod and the cladding surface and the temperature difference between the cladding and the coolant. Heat transfer cocfficients calculated from these data were $3600 \mathrm{Btu} / \mathrm{hr} \cdot \mathrm{ft}^{2} \cdot{ }^{\circ} \mathrm{F}$ before the sinulated LOCA, approximately $4500 \mathrm{btu} / \mathrm{hr} \cdot \mathrm{ft}^{2} \cdot{ }^{\circ} \mathrm{F}$ for up to $2 \mathrm{sec}$ after the LOCA was initiated, and between 11,000 and 45,000 $\mathrm{Btu} / \mathrm{hr} \cdot \mathrm{ft}^{2} \cdot{ }^{\circ} \mathrm{F}$ during the period $2 \mathrm{sec}$ to dryout. Dryout occurred 29.5 seconds after pipe rupture.

This information is important because it indicates that (1) heat transfer coefficients during the depressurization may be several times greater than estimates using steady state data, and (2) good cooling continued for a period of time somewhat greater than the time constant (the time to remove 1/e times the Initial stored energy of the rods) of the heater rods. If (1) and (2) are true in the reactor accident case, the temperature of the fuel rod cladding at the time of initiation of exiergency cooling could be as low as 1400 to $1500^{\circ} \mathrm{F}$ at the hot spot.

Fig. 10 shows cladding temperatures of the other End Tag F-10

heaters in the 7-rod array versus time during and after the depressurization. (Note that on the time scale of Fig. 10 and 11 the LOCA was Initfated at 4.2 sec ratier, than the $0.23 \mathrm{sec}$ indicated in Fig. 9.) The temperatures of rods 1 and 4 (with zero heat flux) 


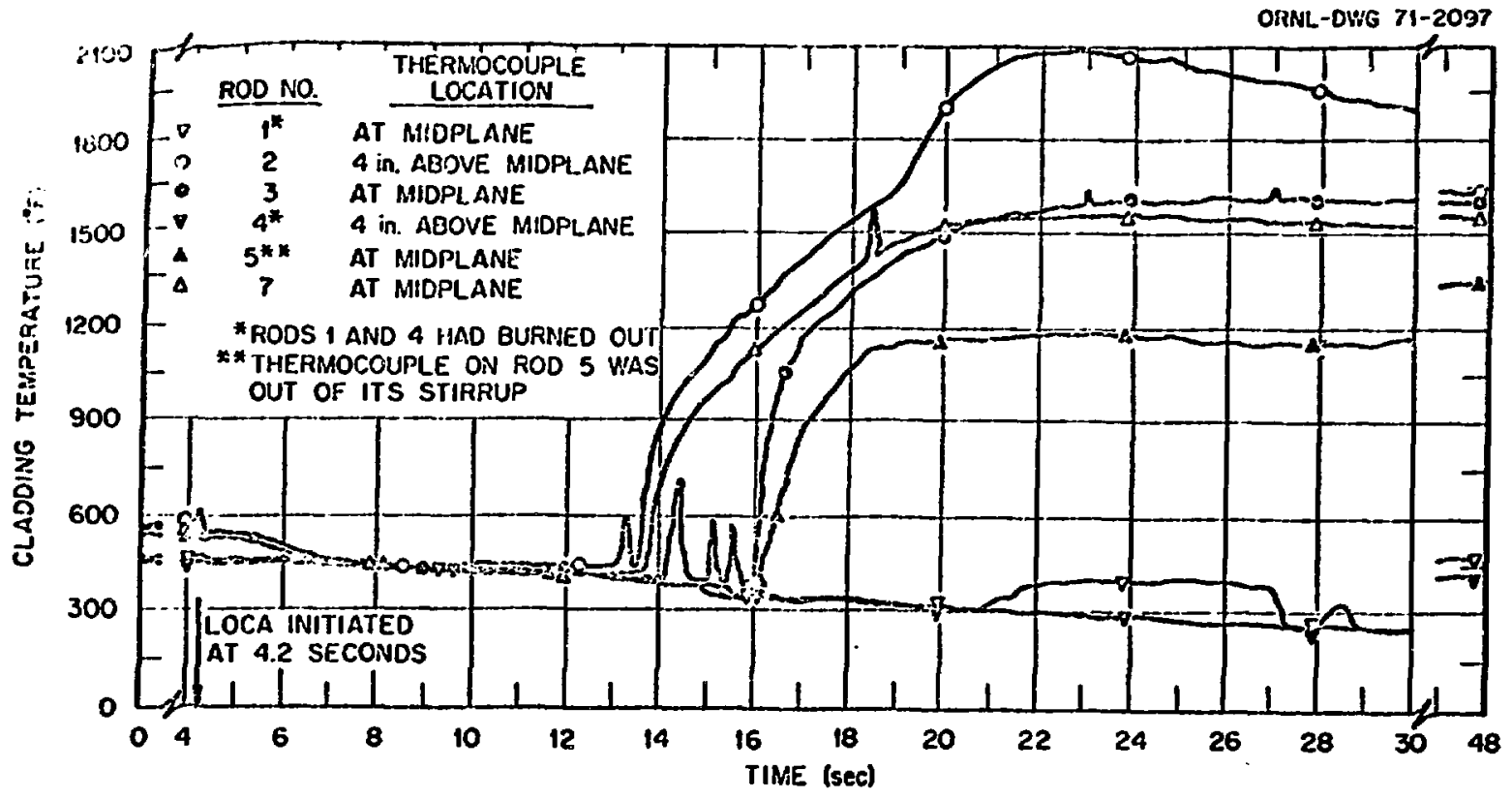

Fig. $\int_{12}^{0}$. Cladding Surface Temperature Traces as a Function of Time After Blowdown.

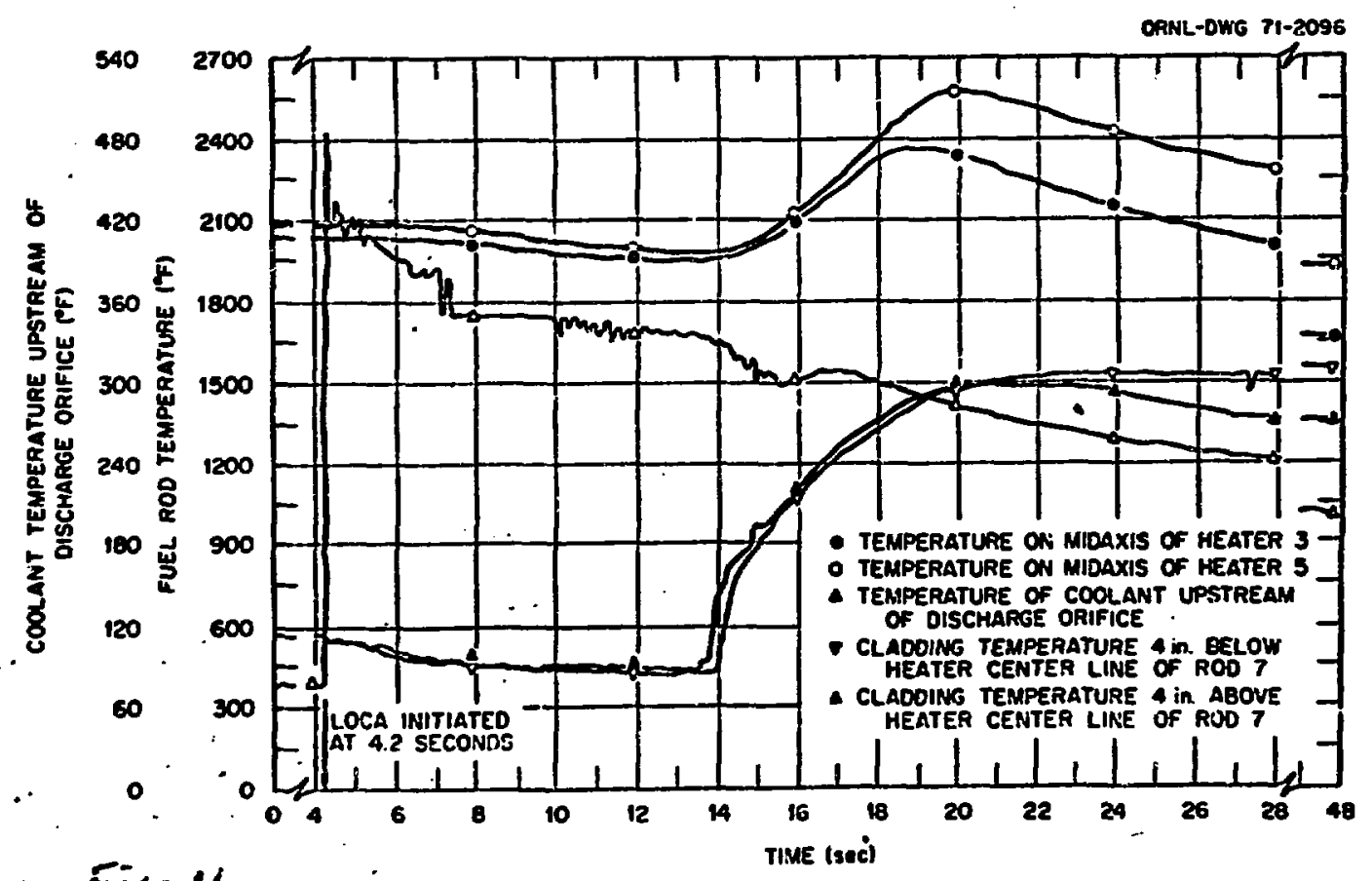

Fif. 1.12, Additional system and Heater Rod Tcmperature Data Obtained During Blowdown Test. 
follow the coolant temperature closely. All the cladding surface temperatures (on the powered rods) decreased about $100^{\circ} \mathrm{F}$ during the first $3 \mathrm{sec}$ of blowdown as bulk boiling started and then remained within about $30^{\circ} \mathrm{F}$ of the coolant temperature until dryout occurred. During this perjod the heat flux renained constant. Apparently dryout was followed by a period of flow reversal, or sequential retting as evidenced by the cladding temperature spikes between 13 and $16 \mathrm{sec}$ on the time scale. (Thermocouples not reported did not record.)

Cladding temperature traces at two additional stations, the temperature of the coolant upstream of the discharge orifice, and rod axis temperatures are shown on Fig. 11. Power cutoff to rod 3 was at 18.2 sec and to rod 5 at 19.2 sec; that is, approximately 1 sec before each reached maximum temperature. The very rapid rise in the temperature of the blowdown coolant upstream of the rupture disks marks the iniation of depressurization and is to be noted as a reference point for pipe rupture. $\because \quad \because$ On the basis of these preliminary tests it appears that energy removal from fuel rods during the period of depressurization associated with the LOCA may be consideiably greater than currently assumed. However, the data are not to be applied directly to 
any reactors. The conditions of these tests are not the same as the conditions of a reactor. This may be seen by exanination of Table II. In addition, the boundary conditions of a large fuel bundle array are different than that of a single rod or a 7-rod array; the flow in these tests is more unidirectional and does not develop the radial flow expected in a large reacto: core. Niost important, the reversal of flow direction in a 12-ft long assembly that would occur in a reactor plant if an inlet pipe vere to rupture was not examined. This flow reversal could result in (film bilmir ) rextical heat flux condition as soon as depressurizatign startéd because of the high enthalpy entering the heated region.

The most important single aspect of these tests results is that data may be obtained using electrieally heated rods under conditions that approach the eivifoniment of a Loss-of-Coolant Accident. Thus it is possible to test our ability to describe "what occurs" . under these circumstances up to the destruction of the heaters.

$\therefore$ The lack of instruments for measuring rapid twophase transient flow in pipes is a great háandicap in interpreting results mechanistically. The shape and similarity of the transient temperature difference curves in the single and 7 -rod tests suggests strongly 
the devclopment of an anular flow situation with decreasing pressure and increasing stean quality. This -

situation would result in highi heat transfer coefficicits: that would increase until dryout occurred.

\title{
Conclusions
}$$
\text { tgson }
$$

An experitient facility has been built whjich may
\end{abstract} be used to perform tests to neasure the thernal response of heaters in pressure blowdown transient" similar in time scale to a Pressurized Water Reactor Lossof-Coolant Accident. Electrical heaters have been developed which approximate the thermai transport characteristics of a nuclear fuel pin and these rods have been operated at heat flux levels comparable to a nuclear full pin.

Theoef Fest results indicatedheat transfer coefficients during depressurization trat were greater than $3000 \mathrm{Btu} / \mathrm{hr} \cdot \mathrm{ft}^{2 .{ }^{\circ} \mathrm{F}}$ for time periods larger than the heater heat transport time constants. behavier

Tise spape of the surface to coolant temperature difference suggest $\frac{\&}{\text { a }}$ a rapid development of annular two-phase fiow whifch lasted unt11 surface dryout occurred.

Additional testing is required under geometrical and thermodynawic conditions more nearly like a reacfiner can be tor before reactor relevant conclusions afe drawn. 
These variabjes include heater geonetry, coolant inlet and outlet flow and enthalpy, the coolant prossure transient and the heater siternal pressure.

\section{List of Figures}

1. Depressurization Loop

2. Special lleater with Hollow Ceramic Core to Permit Gas Transport within Heater Rod

3. Centerline Temperature Rise Versus Rod Power or Heat Flus

4. Comparison of Time Constant Data Obtained During Depressurization l'ests with Low Pressure Data

5. Expansion Test of Internally Pressurized Heater Rod

6. Thermal Response of beater Rod to LOCA

7. Thermal Respcnse of. Heater Rod to LOCA

8. Plan View of Test Seven-Rod Cluster

9. Experimental Data from Seven-Rod Depressurization . Experiment Including Central Rod Thermal Data

10. Cladding Surface Temperature Traces

"11. Additional Cladding and Heater Axis Temperature with Stean Discharge Temperature

Ref. Code 


\section{References}

1. Tennessee Val.Jey Autherity, "Browns Ferry Nuclear Power. Station, Preliminary Safety Analysis and Design Report," Docket Nos. 50-259 and 50-260 (1966).

2. Duke Yower Company, "Oconee Nuclear Power Station, Units 1 and 2 Preliminary Safety Analysis Report," Docket Nos. 50-269 and 50-270 (1966).

3. C. G. Lawson, "Emergency Cooling Systeus of Light Water Cooled Reactors," ORNL-NSIC-24, Oak Ridge National Laboratory (October 1968).

4. J. F. White, "AटC Fuels and Matèrials Development Program Progress Report No. 76," GEMP-1000, PP. 229-280 (September 1968).

5. D. O. Hobson, M. F. Osborne, and G. H. Parker, "Comparison of Rupture Data from Irradiated Fuel Bod and Cladding," Huct. Tecinnot. 11(4), 479-491, August 1971.

6. C. G. Lawson, Cladding Behavior in Loss-of-Coolant Accident, Pp. 23-26, "ORNL Nuclear Safety Research and Development Program Bimonthly Report

.. for May-June 1969," ORNL-TM-2663 (September 1969).

7. J. 0.. Cerman, A. S. Kttzex, F. F. Cadek, R. H. Lejise, D. P. Dominicio, "PWR Full Length Emergency Cooling Heat Transfer," USAEC Report WCAP7435, January 1970. 
8. F. F. Cadek, D. P. Dominicio, and R. H. Leyse, "PWR Full Length Euergency Cooling Heat Iransfer, Group II Test Report, USAEC Report WCAP-7544, September 1970.

9. W. H. Rettig, G. A. Jayne, K. V. Moore, .C. E. Slater, M. L. Uptmor, "RELAP3---A Computer Program for Reactor Blowdown Analysis," IN-132I, June 1970.

10. C. J. Hocevar and T. W. Wineinger, "THETA1-B, A Computer Code for Nuclear Reactor Core Thermal Analysis," IN-1445, February 1971. -11. J. O. Cermak, L. S. Tong, J. E..Casterline et a1., "DNB in Rod Bundles During Pressure Blowdown," ASHE Paper No. 70HT12.

12. B. E. Bingham and A. L. Lowe, Jr., "Application of Experimental Data to Analytical Evaluation of Cladding Failure Distribution," Nucl. Tech., 11(4), 521-525, August 1971 . 
Table III. Power Distribution

in Rods of Seven-Rod Cluster

\begin{tabular}{ccc}
\hline Rod & $\begin{array}{c}\text { Power } \\
(\mathrm{kW})\end{array}$ & $\begin{array}{c}\text { Linear Heat } \\
\text { Rating } \\
\text { (kW/ft) }\end{array}$ \\
\hline 1 & 0 & 0 \\
2 & 32.3 & 16.15 \\
3 & 29.4 & 14.7 \\
4 & 0 & 0 \\
5 & 32.3 & 16.15 \\
6 & 37.2 & 18.6 \\
7 & 34.9 & 17.45 \\
Totai & 166.1 & \\
\hline
\end{tabular}

